\title{
Discontinuities in the late 1960's in different atmospheric data products
}

\author{
Holger Pohlmann ${ }^{1,2}$ and Richard J. Greatbatch ${ }^{1}$ \\ Received 21 July 2006; revised 10 October 2006; accepted 19 October 2006; published 18 November 2006.
}

[1] An analysis of the onset and spatial extent of discontinuities in the late 1960's in different atmospheric data products is performed. Discontinuities are found in both the NCEP/NCAR and ERA-40 reanalyses in various surface variables including sea level pressure (SLP) in both data sets over Africa, in the NCEP/NCAR reanalysis also over Asia and in the ERA-40 reanalysis also over South America, and precipitation in the NCEP/NCAR reanalysis over North Africa. Discontinuities are also found in $2 \mathrm{~m}$ air temperature in both reanalyses. The discontinuities in SLP extend into the lower troposphere. The main cause of these discontinuities appears to be missing or limited synoptic data prior to the late 1960's. Citation: Pohlmann, H., and R. J. Greatbatch (2006), Discontinuities in the late 1960's in different atmospheric data products, Geophys. Res. Lett., 33, L22803, doi:10.1029/2006GL027644.

\section{Introduction}

[2] Few conventional meteorological observational records reach as far back as the 17 th century. An exception is that of central England temperature [Manley, 1974], but worldwide observations over the continents and oceans are remarkably sparse by today's standards, even through the late 19th and early 20th century until after the Second World War. One challenge in the study of climate is that among long records there are discontinuities owing to changes in measurement methods. An example is the method of obtaining sea water temperature on board ships. This has changed from the use of wooden to other bucket materials and a greater use of engine room intake and hull sensors resulting in systematic biases [Folland and Parker, 1995]. In reanalysis projects, observations are combined with a numerical weather prediction model to obtain homogeneous atmospheric data sets in the sense that the model and the assimilation technique do not change. However, discrepancies exist also in these data sets due to flaws in the model and assimilation technique and because the quality and quantity of observational data assimilated has changed over time. The introduction of satellite measurements in the late 1970's has lead to systematic errors notable in the tropical atmosphere [e.g., Santer et al., 1999; Trenberth et al., 2001; Sturaro, 2003; Sterl, 2004; Kinter et al., 2004; Trenberth and Smith, 2005; Greatbatch and Rong, 2006]. Among a number of reanalyses, the National Centers for Environmental Prediction/National Center for Atmospheric Research (NCEP/NCAR) [Kalnay et al., 1996] and European

\footnotetext{
${ }^{1}$ Department of Oceanography, Dalhousie University, Halifax, Nova Scotia, Canada.

${ }^{2}$ Now at Max-Planck-Institut für Meteorologie, Hamburg, Germany.
}

Copyright 2006 by the American Geophysical Union. 0094-8276/06/2006GL027644\$05.00
Centre for Medium-Range Weather Forecast 40-years (ERA-40) [Uppala et al., 2005] reanalyses cover the period prior to the late 1970's and are considered in this study. These data sets reveal strong discontinuities in the late 1960's, being in some details even stronger than those of the 1970's. However, these early anomalies have not been fully explored from a temporally and geographically localized perspective.

[3] Yang et al. [2002] note a discrepancy over eastern Asia between the NCEP/NCAR reanalysis and the Trenberth sea level pressure (SLP) data set [Trenberth and Paolino, 1980] in a period prior to the late 1960's in winter. This issue has been explored further by Inoue and Matsumoto [2004], who point to SLP discrepancies over Asia in summer between the NCEP/NCAR and ERA-40 reanalyses. Greatbatch and Rong [2006] show that the SLP problem over Asia is connected with a similar problem over North Africa in summer. However, the discrepancies between the NCEP/NCAR reanalysis and data from other sources over Asia and North Africa also coincide with strong transitions in the global climate system. The Sahel region in North Africa underwent a prolonged drought in the late 1960's [e.g., Ward et al., 1999]. Hurrell and Folland [2002] note a change in the summer atmospheric circulation over the North Atlantic that also took place in the late 1960's and they speculate that this regime shift may be connected with the Sahel drought. Also in the late 1960's the winter rainfall of Southwest Australia decreased considerably [Indian Ocean Climate Initiative Panel, 2002], and Baines [2005] attributes the long-term decrease of winter rainfall over Australia to the African monsoon. These examples highlight the importance of distinguishing between real trends and artificial transitions.

\section{Data}

[4] In this study the NCEP/NCAR [Kalnay et al., 1996; Kistler et al., 2001] and ERA-40 [Uppala et al., 2005] reanalyses are compared with each other and with gridded SLP observations from the HadSLP2 data set [Allan and Ansell, 2006], gridded precipitation and temperature observations from the Climate Research Unit (CRU) TS2.1 data set [Mitchell and Jones, 2005], and station observations from the NCAR ds570.0 data set [Spangler and Jenne, 1999]. The NCEP/NCAR reanalysis covers the period 1948-2005 whereas the ERA-40 reanalysis covers the period September 1957-August 2002. We employ the monthly means of both data sets. The HadSLP2 data set is a combination of monthly globally-complete fields of air pressure observations on a $5^{\circ}$ by $5^{\circ}$ latitude-longitude grid from 1850-2004. The CRU data set is available on a $0.5^{\circ}$ by $0.5^{\circ}$ latitude-longitude grid for the period 1901-2002. The ds570.0 data set has data from over 4700 different stations and goes as far back as the mid-1700's. 
(a)

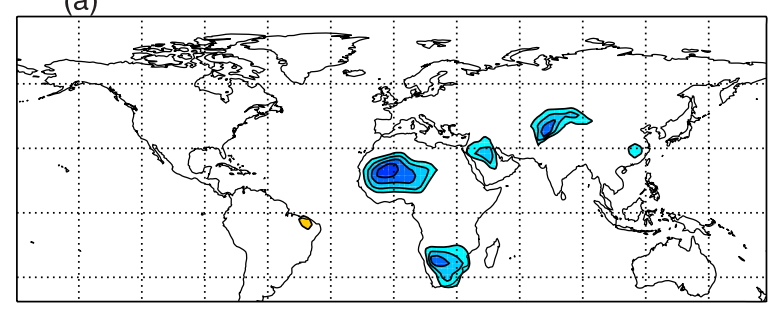

(b)

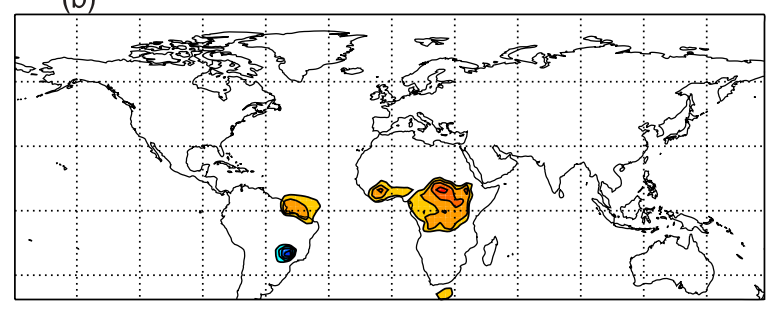

(c)

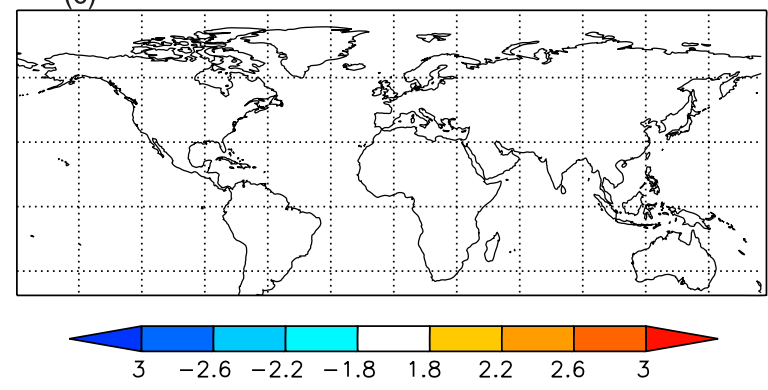

Figure 1. Decadal mean SLP differences [standard deviations], 1958-1967 minus 1968-1977, for the (a) NCEP/ NCAR reanalysis, (b) ERA-40 reanalysis, and (c) HadSLP2 data set.

[5] SLP is the most widely analyzed quantity in meteorological weather maps. To derive SLP maps, the surface pressure at altitude must be reduced to sea level. However, variations in the method used for pressure reduction can cause errors [e.g., Ingelby, 1995; Mohr, 2002]. Moreover, the assimilation of surface pressure depends on geographical elevation, which in turn varies with model resolution. As such, the relatively high T159 resolution of the ERA-40 reanalysis model is more advantageous than the T62 resolution of the NCEP/NCAR reanalysis model. By comparison, the $5^{\circ} \times 5^{\circ}$ grid of the HadSLP2 data set is rather coarse.

\section{Results}

[6] Figure 1 shows global maps of the occurrence of SLP discontinuities in the late 1960's in the NCEP/NCAR, ERA40 and the HadSLP2 data sets. Discontinuities are defined here as the SLP differences between the decades 19581967 and 1968-1977 that exceed 1.8 standard deviations of the annual variance in the two decades. The maps are limited to geographical latitudes north of $40^{\circ} \mathrm{S}$ to account for sparse observational coverage in the Southern Ocean and Antarctic region, especially prior to the late 1970's [e.g., Hines et al., 2000]. SLP discontinuities in the late 1960 's are present in the NCEP/NCAR reanalysis over North/West Africa, South Africa, the Middle East and Asia.
In the ERA-40 reanalysis, these are apparent over Central Africa and South America while in the HadSLP2 data set no significant discontinuities in the late 1960's are found. The seasonal means (not shown) reveal discontinuities in the NCEP/NCAR reanalysis over North Africa and Asia that are strongest in boreal summer (June-July-August), and over South Africa and the Middle East in boreal spring (March-April-May). The discontinuity over Central Africa in the ERA-40 reanalysis is strongest in boreal fall (September-October-November).

[7] Figure 2 shows the time series of the difference between the NCEP/NCAR and ERA-40 reanalyses of area averaged SLP. The areas over which the data are averaged are (Figure 2a) North Africa $\left(10-25^{\circ} \mathrm{N}, 10^{\circ} \mathrm{W}-20^{\circ} \mathrm{E}\right)$, (Figure $2 \mathrm{~b}$ ) the Middle East $\left(25-35^{\circ} \mathrm{N}, 30-50^{\circ} \mathrm{W}\right.$ ), (Figure 2c) Central Africa $\left(10^{\circ} \mathrm{S}-10^{\circ} \mathrm{N}, 10-30^{\circ} \mathrm{E}\right)$, (Figure $2 \mathrm{~d}$ ) South Africa $\left(10-30^{\circ} \mathrm{S}, 20-40^{\circ} \mathrm{E}\right)$, (Figure 2e) Central Asia $\left(40-50^{\circ} \mathrm{N}, 70-90^{\circ} \mathrm{E}\right)$, and (Figure $2 \mathrm{f}$ ) South America $\left(15-25^{\circ} \mathrm{S}, 55-45^{\circ} \mathrm{W}\right)$. The time series representing the SLP difference over North Africa, the Middle East and Central Africa show an abrupt discontinuity at the turn of the year $1966 / 1967$. A similar discontinuity is also present in the time series representing the SLP difference over South Africa, but here it is less robust as the time series shows more variability, especially in the period prior to the late 1960 's. The discontinuity over Asia in the late 1960's is restricted to the Northern Hemisphere (NH) summer season. Interestingly, in the period between the late 1960's and the late 1970's there is also a discrepancy between the two reanalyses that is restricted to $\mathrm{NH}$ winter months. The time series representing the SLP differences over South America also shows a discontinuity in the late 1960's but, in contrast to the previous discontinuities, here the second decade has a negative bias rather than the first one.

[8] Discontinuities occur in regions where observational data coverage is relatively sparse. However, some station data are available in these problematic regions. Data are selected from the observational station data set ds570.0 to get the most complete records in each of the problematic region (Table 1). The time series are compared with the data from the NCEP/NCAR, ERA-40 and HadSLP2 data sets bilinear interpolated at the station locations (Figure 3). In all of these SLP time series the previously discussed discontinuities in the late 1960's are not apparent in the station data. Specifically, none of the discontinuities in the late 1960's of the NCEP/NCAR data over North Africa, the Middle East, South Africa, and Asia, nor the discontinuity in the late 1960's of the ERA-40 data over Central Africa and South America are resolved by the station data. Interestingly, another discontinuity of the NCEP/NCAR data is apparent in the late 1970's over Central Africa (Figure 3c).

Table 1. List of Observational Stations Used in the Present Study

\begin{tabular}{lllcl}
\hline Index No. & \multicolumn{1}{c}{ Station Name } & Latitude & Longitude & $\begin{array}{c}\text { Elevation } \\
{[\mathrm{m}]}\end{array}$ \\
\hline 612650 & Mopti & $14.5^{\circ} \mathrm{N}$ & $4.1^{\circ} \mathrm{W}$ & 272 \\
623780 & Helwan & $29.9^{\circ} \mathrm{N}$ & $31.1^{\circ} \mathrm{E}$ & 141 \\
644560 & Makoua & $0.0^{\circ} \mathrm{N}$ & $15.7^{\circ} \mathrm{E}$ & 346 \\
672970 & Beira/Sacadura Cabal & $19.8^{\circ} \mathrm{S}$ & $34.9^{\circ} \mathrm{E}$ & 16 \\
384570 & Taskent & $41.6^{\circ} \mathrm{N}$ & $69.3^{\circ} \mathrm{E}$ & 428 \\
836180 & Tres Lagoas & $20.8^{\circ} \mathrm{S}$ & $51.7^{\circ} \mathrm{W}$ & 314 \\
647000 & Fort-Lamy & $12.1^{\circ} \mathrm{N}$ & $15.0^{\circ} \mathrm{E}$ & 295 \\
\hline
\end{tabular}


(a)

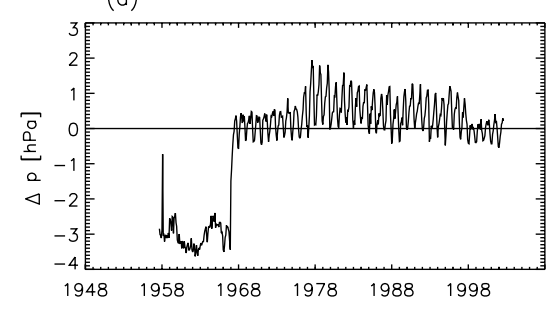

(c)

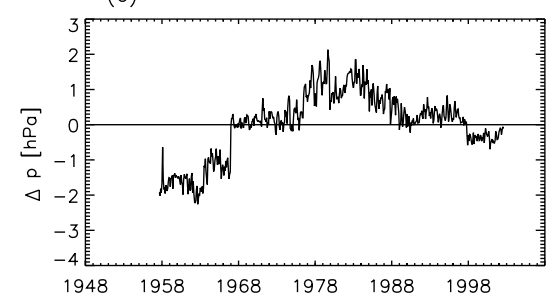

(e)

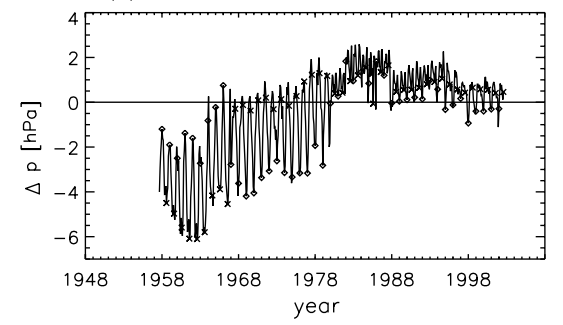

(b)

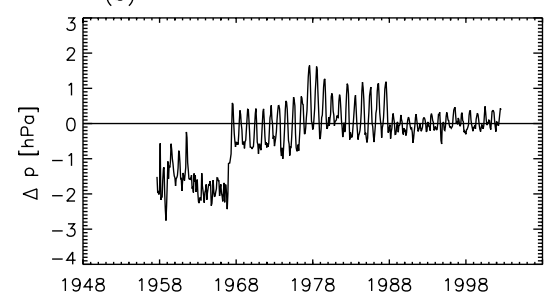

(d)

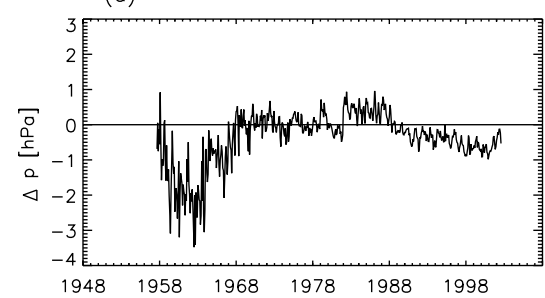

(f)

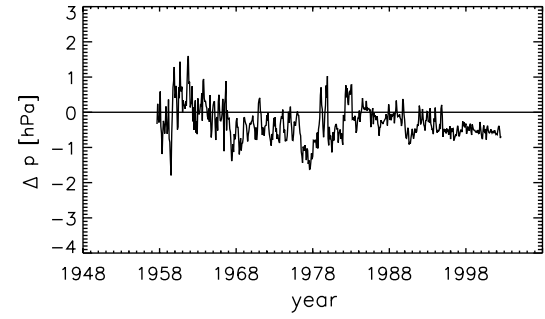

Figure 2. Time series of area and monthly mean SLP differences [hPa], NCEP/NCAR minus ERA-40 reanalysis, averaged over (a) North Africa, (b) the Middle East, (c) Central Africa, (d) South Africa, (e) Central Asia and (f) South America. In Figure 2e, differences in January and August are marked with a diamond and cross, respectively.
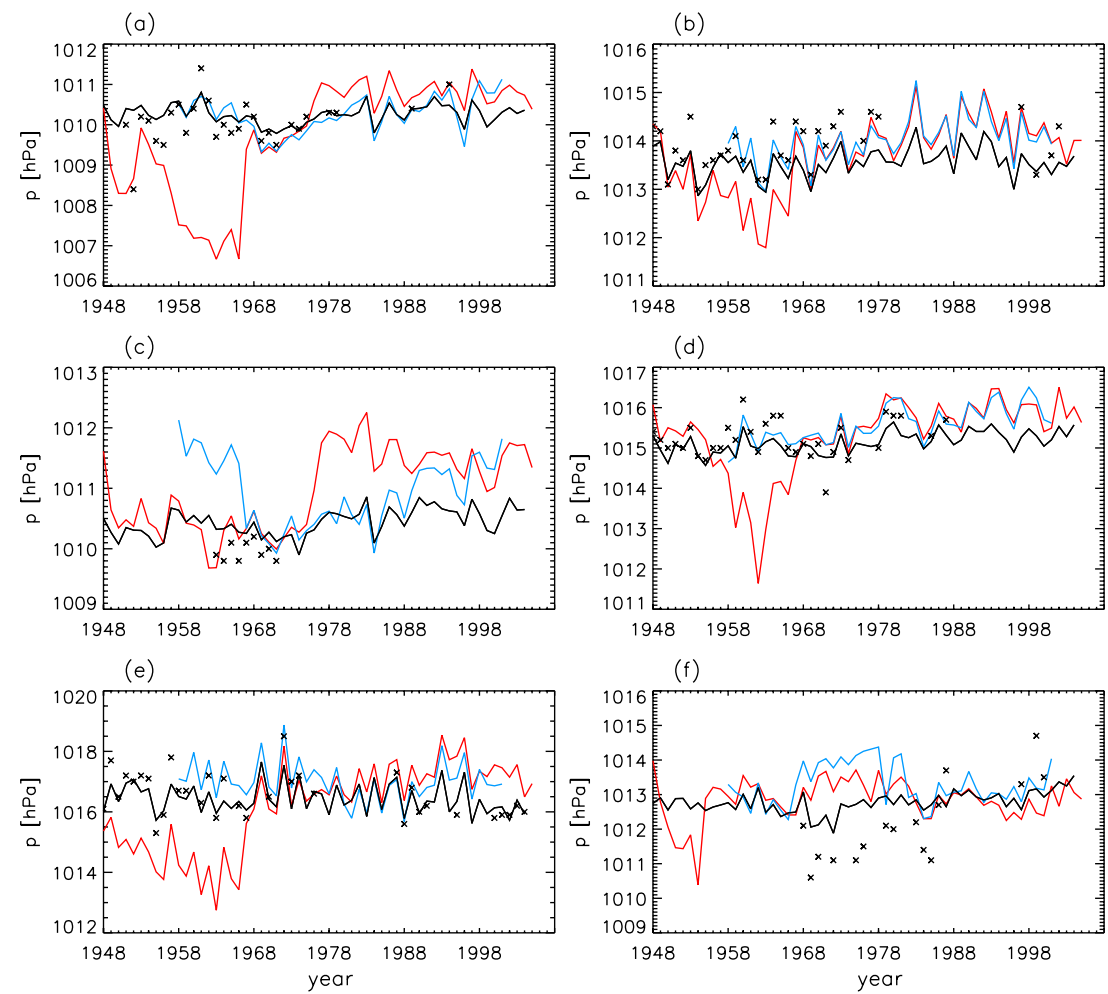

Figure 3. Time series of annual mean SLP from station observations (crosses) and for data interpolated to station locations from the NCEP/NCAR (red), ERA-40 (blue), and HadSLP2 (black) data sets. The stations are in (a) Northwest Africa (Mopti), (b) Northeast Africa (Helwan), (c) Central Africa (Makoua), (d) South Africa (Beira), (e) Central Asia (Taskent) and (f) South America (Tres Lagoas). 

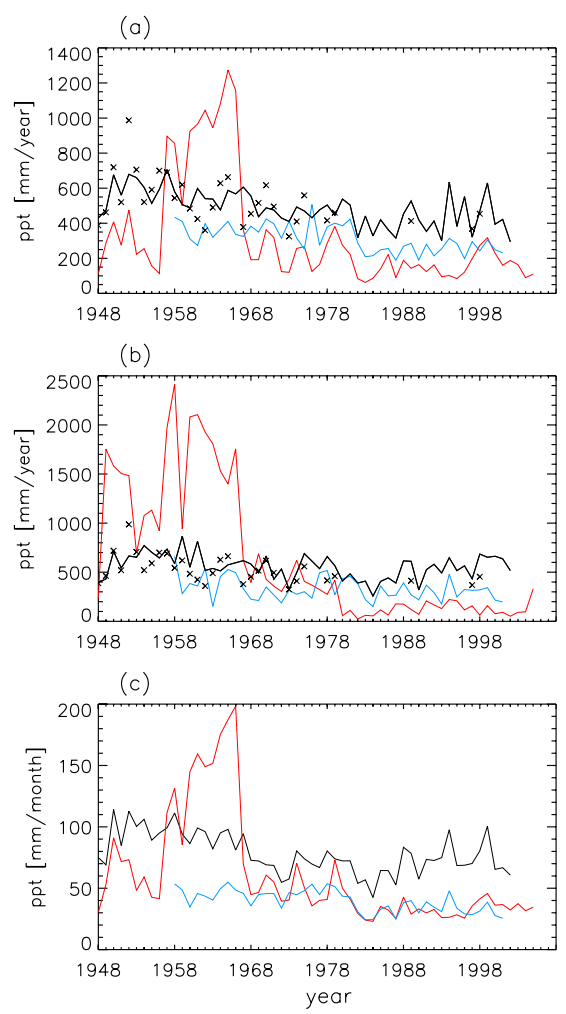

Figure 4. Time series of annual mean precipitation from observations at two stations in North Africa (crosses) for (a) Mopti and (b) Fort-Lamy, and for data interpolated to station locations and (c) area averaged Sahel summer (June-September) precipitation from the NCEP/NCAR (red), ERA-40 (blue), and CRU (black) data sets.

Both reanalyses disagree with observations over South America especially during the late 1960's to the early 1980's (Figure 3f).

[9] The SLP discontinuities in the late 1960's are also evident in the lower troposphere. Discontinuities in the late 1960 's are present in the $850 \mathrm{hPa}$ and $700 \mathrm{hPa}$ geopotential height fields of the NCEP/NCAR and ERA-40 reanalyses in regions where the largest SLP discontinuities are found (not shown). We have also examined $2 \mathrm{~m}$ air temperature (not shown). There are discontinuities in the late 1960's in the NCEP/NCAR reanalysis over North and South Africa, the Middle East, Asia extending over the Japan Sea, and Southern Europe extending over the North Atlantic, having no correspondence, at least over land, in the observational data set CRU TS2.1. There is also a marked shift in the ERA-40 $2 \mathrm{~m}$ air temperature over South America from a warm to a cool bias in 1967 as described by Betts et al. [2004], a problem that coincides with the introduction of synoptic surface data from Brazil in the ERA-40 reanalysis in 1967 [Betts et al., 2004; Simmons et al., 2004; Uppala et al., 2005].

[10] Discontinuities have also been detected in the late 1960 's in the precipitation data of the two reanalyses. Discontinuities in the NCEP/NCAR reanalysis are found over the Sahel region in North Africa. The reduction of precipitation is in this region much less intense in the ERA-40 and CRU data sets. Figure 4 shows two examples of the precipitation time series from stations located in (Figure 4a) Mali (Mopti) and (Figure 4b) Chad (Fort-Lamy) together with the data interpolated to these locations from the NCEP/NCAR, ERA-40 and CRU data sets. Figure 4c shows the area averaged precipitation over the West Sahel region $\left(12^{\circ}-20^{\circ} \mathrm{N}, 10^{\circ} \mathrm{W}-10^{\circ} \mathrm{E}\right)$ in the rainy season (JuneSeptember). This illustrates that precipitation in the NCEP/ NCAR reanalysis is overestimated in the North African region especially during the late 1950 's to late 1960 's. In the ERA-40 reanalysis, and after the late 1960's also in the NCEP/NCAR reanalysis, precipitation appears to be underestimated over the Sahel region. These results caution use of either reanalysis product to investigate the dynamics of the drying trend.

\section{Conclusions}

[11] The geographical extent of existing discontinuities in surface variables during the late 1960's as represented by different atmospheric data products are systematically investigated in this study by direct comparison with observations. The strength of the discontinuities and the intercomparison between different data sets suggests that the suspected climate transitions indeed appear to be artificial. These include SLP discontinuities in the NCEP/NCAR reanalysis over North/West and South Africa, the Middle East, and Central Asia, and in the ERA-40 reanalysis over Central Africa and South America. Discontinuities are also found in $2 \mathrm{~m}$ air temperature in both reanalyses. Precipitation discontinuities are found in the NCEP/NCAR reanalysis over North Africa. It follows that the NCEP/NCAR reanalysis data may not be appropriate for analyzing the dynamics of the drying trend over North Africa.

[12] The number of synoptic observations available for assimilation into the reanalysis systems are much lower prior to the late 1960's than after. The discussed discontinuities in the late 1960's are probably due to missing or limited synoptic data from many countries prior to 1967. For example, the missing synoptic data from Brazil appear to result in the $2 \mathrm{~m}$ air temperature discontinuities in the ERA-40 reanalysis over South America [Betts et al., 2004; Simmons et al., 2004]. However, the problem is also present on other continents and is even more apparent in the NCEP/ NCAR reanalysis.

[13] The strongest discontinuities in the late 1960's occur in the reanalyses over land. In the early period when no observational data are available to be assimilated into the reanalyses the mean climate is different to that of the later period. Model improvements (e.g., a higher grid resolution or improved model parameterizations) may reduce the differences between the observed and simulated climate and therefore lead to less strong discontinuities. Additionally, newly developed land surface observation techniques from satellites may also improve the surface climate in future reanalysis systems.

[14] Acknowledgments. This research is funded by NSERC and CFCAS in support of the Canadian CLIVAR Research Network. We thank Rick Danielson for his comments on this paper. The NCEP/NCAR reanalysis data are obtained from the Climate Diagnostics Center of the National Oceanic and Atmospheric Administration in the USA (http:// www.cdc.noaa.gov). The ERA-40 reanalysis data are downloaded from the ECMWF data server in the UK (http://data.ecmwf.int/data). The HadSLP2 data are received from the Hadley Centre of the Met Office in the UK 
(http://www.hadobs.org). The high-resolution CRU TS2.1 precipitation and temperature data are constructed and supplied by T. D. Mitchell (http:// www.cru.uea.ac.uk/ timm/grid/CRU_TS_2_1.html). The station observations are obtained from the Data Support Section of the NCAR in the USA (http://dss.ucar.edu/datasets/ds570.0).

\section{References}

Allan, R. J., and T. J. Ansell (2006), A new globally complete monthly historical gridded mean sea level pressure data set (HadSLP2): $1850-$ 2004, J. Clim., in press.

Baines, P. G. (2005), Long-term variations in winter rainfall of southwest Australia and the African monsoon, Aust. Meteorol. Mag., 54, 91-102.

Betts, A. K., J. H. Ball, P. Viterbo, A. Dai, and J. Marengo (2004), Hydrometeorology of the Amazon, ERA-40 Project Rep. Ser. 22, 15 pp., Eur. Cent. for Medium-range Weather Forecasts, Reading, U.K.

Folland, C. K., and D. E. Parker (1995), Correction of instrumental biases in historical sea surface temperature data, Q. J. R. Meteorol. Soc., 121, $319-367$.

Greatbatch, R. J., and P.-P. Rong (2006), Discrepancies between different northern hemisphere summer atmospheric data products, J. Clim., 19, $1261-1273$

Hines, K. M., D. H. Bromwich, and G. J. Marshall (2000), Artificial surface pressure trends in the NCEP-NCAR reanalysis over the Southern Ocean and Antarctica, J. Clim., 13, 3940-3952.

Hurrell, J. W., and C. K. Folland (2002), A change in the summer atmospheric circulation over the North Atlantic, CLIVAR Exchanges, 25, 5254.

Indian Ocean Climate Initiative Panel (2002), Climate variability and change in south west Western Australia, report, 34 pp., Western Aust. Dept. of Environ., Perth, West. Aust., Australia.

Ingelby, N. B. (1995), Assimilation of station level pressure and errors in station height, Weather Forecast., 10, 172-182.

Inoue, T., and J. Matsumoto (2004), A comparison of summer sea level pressure over east Eurasia between NCEP-NCAR reanalysis and ERA-40 for the period 1960-1999, J. Meteorol. Soc. Jpn., 82, 951-958.

Kalnay, E., et al. (1996), The NCEP/NCAR 40-year reanalysis project, Bull. Am. Meteorol. Soc., 81, 2165-2177.

Kinter, J. L., III, M. J. Fennessy, V. Krishnamurthy, and L. Marx (2004), An evaluation of the apparent interdecadal shift in the tropical divergent circulation in the NCEP-NCAR reanalysis, J. Clim., 17, 349-361.

Kistler, R., et al. (2001), The NCEP-NCAR 50-year reanalysis: Monthly means CD-ROM and documentation, Bull. Am. Meteorol. Soc., 82, $247-$ 267.

Manley, G. (1974), Central England Temperatures: Monthly means 1659 to 1973, Q. J. R. Meteorol. Soc., 100, 389-405.
Mitchell, T. D., and P. D. Jones (2005), An improved method of constructing a database of monthly climate observations and associated highresolution grids, Int. J. Climatol., 25, 693-712.

Mohr, M. (2002), Problems with the mean sea level pressure fields over the western United States, Mon. Weather Rev., 132, 1952-1964.

Santer, B. D., J. J. Hnilo, T. M. L. Wigley, J. S. Boyle, C. Doutriaux, M. Fiorino, D. E. Parker, and K. E. Taylor (1999), Uncertainties in observationally based estimates of temperature change in the free atmosphere, J. Geophys. Res., 104, 6305-6334.

Simmons, A. J., P. D. Jones, V. da Costa Bechthold, A. C. M. Beljaars, P. W. Kallberg, S. Saarien, S. M. Uppala, P. Viterbo, and N. Wedi (2004), Comparison of trends and variability in CRU, ERA-40 and NCEP-NCAR analyses of surface temperature, J. Geophys. Res., 109, D24115, doi:10.1029/2004JD005306.

Spangler, W. M. L., and R. L. Jenne (1999), World monthly surface station climatology, report, Data Support Sect., Sci. Comput. Div., Natl. Cent. for Atmos. Res., Boulder, Colo. (Available at http://dss.ucar.edu/ds570.0)

Sterl, A. (2004), On the (in)homogeneity of reanalysis products, J. Clim., $17,3866-3873$.

Sturaro, G. (2003), A closer look at the climatological discontinuities present in the NCEP/NCAR reanalysis temperature due to the introduction of satellite data, Clim. Dyn., 21, 309-316.

Trenberth, K. E., and D. A. Paolino (1980), The Northern Hemisphere sealevel pressure data set: Trends, errors and discontinuities, Mon. Weather Rev., 108, 855-872.

Trenberth, K. E., and L. Smith (2005), The mass of the atmosphere: A constraint on global analyses, J. Clim., 18, 864-875.

Trenberth, K. E., J. W. Stepaniak, J. W. Hurrell, and M. Fiorino (2001), Quality of reanalyses in the tropics, J. Clim., 14, 1499-1510.

Uppala, S. M., et al. (2005), The ERA-40 re-analysis, Q. J. R. Meteorol. Soc., 131, 2961-3012, doi:10.1256/qj.04.176.

Ward, M. N., P. J. Lamb, D. H. Portis, M. el Hamly, and R. Sebbari (1999), Climate variability in northern Africa: Understanding droughts in the Sahel and the Maghreb, in Beyond El Niño: Decadal and Interdecadal Climate Variability, edited by A. Navarra, pp. 119-140, Springer, New York.

Yang, S., K.-M. Lau, and K.-M. Kim (2002), Variations of the East Asian Jet Stream and Asian-Pacific-American winter climate anomalies, J. Clim., 15, 306-325.

R. J. Greatbatch, Department of Oceanography, Dalhousie University, Halifax, Nova Scotia, Canada.

H. Pohlmann, Max-Planck-Institut für Meteorologie, Bundesstr. 53, 20146 Hamburg, Germany. (holger.pohlmann@zmaw.de) 